に筋肉土キス）を以て，正常同種動物学注射莚置してみ た.この處置群は前述した本菑噞 $\mathrm{B}$ 群に相當するもので あつて，その示寸抗澧保は何れも致死當日のものである （第 2 編第 4 章第 3 項の II を參照）その結果は第二㳖の 如くである。

\begin{tabular}{|c|c|c|}
\hline $\begin{array}{c}\text { 家 䊿鳥 番 鶜 } \\
16 \\
\end{array}$ & $\begin{array}{c}\text { 處置: 回 㩯 } \\
19\end{array}$ & $\begin{array}{c}\text { Mb 抗體底生状况 } \\
200 \times 2\end{array}$ \\
\hline 23 & 40 & $200 \times 8$ \\
\hline 18 & 40 & $500 \times 2$ \\
\hline 24 & 17 & $200 \times 2$ \\
\hline 27 & 30 & 0 \\
\hline
\end{tabular}

No. 27 は正常家鳵 $\mathrm{Mb}$ 處置例 試驗管內抗原は白米病家觅鳥 Mb 10\% 溶液

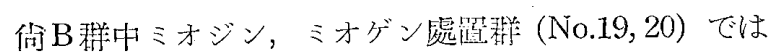

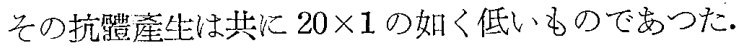

3)小括

以上の䔈驗に徴して白米食を以て飼育せる家垁鳥は，そ の流血中に抗原ともなるべき $\mathrm{Mb}$ の遊出出現友び $\mathrm{Mb}$ 自家抗澧の座生:が見られた. 而してこの血清中の $\mathrm{Mb}$ の存在は白米病後期に於いて認められ，一方 $\mathrm{Mb}$ 自家 抗腊も同じく後期に值が高い倾向にある. 又血清中の $\mathrm{Mb}$ と $\mathrm{Mb}$ 自家抗體との均合關係はその中和による現

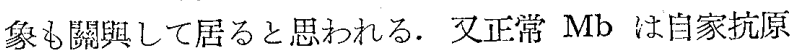
性を持たぬが，白米病家第 $\mathrm{Mb}$ は自家抗原性を獲得する 事子明かにさ机た：而して炎の注射回數の多、程產生き れる $\mathrm{Mb}$ 同種抗體の值も高い.一方ミオジン，ミオゲン は之等の點では殆んど問題にならないと思われる。

(交被以本确文水展江付す)

From the Irvate Medical School (Assist. Professor I. Ono, M. D.)

\title{
Studies on the Experimental Myocarditis due to Myoglobin (III) allergic changes in cardiac tissue and other organs caused by myoglobinantibodies in rice-illness
}

$\mathrm{By}$

W. ISIKAWA

(Received for Publication, Jun. 8, 1953)

\section{ミオグロビンによる實驗的心筋炎 （第 3 報）}

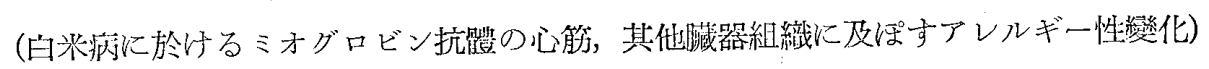

\author{
石川 和 佑

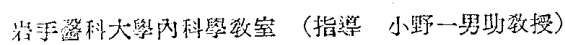

I have already published that allergic myocarditis and allergic changes in the other organs is caused due to the sensitization with chickens $\mathrm{mb}$ in riceillness, and $\mathrm{mb}$ of chicken suffering from rice-illness obtains autoantigenicity, producing thereby autoan- tibodies.

Therefore, I assert that allergic myocarditis and myocardial damage due to $\mathrm{mb}$ was considered to make an important factor for the pathogenesis of beriberi heart.

\section{筑 4 編 總括垪に考按}

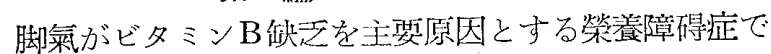
ある事は今日最早や之を疑 5 者がないが，脚氣即らビタ

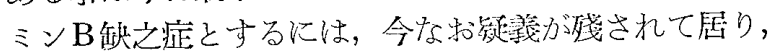
墸學者により之に加 5 る何等加の因子の存在が考虑され 之が䂠究し續けられて來て居る。

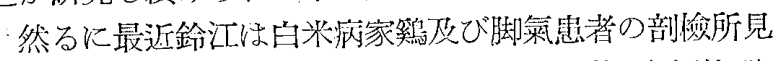

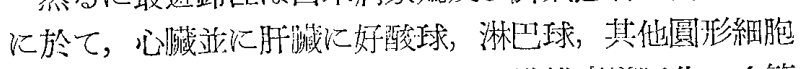

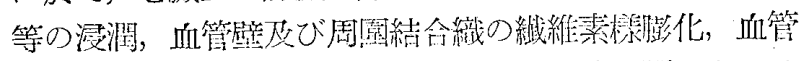

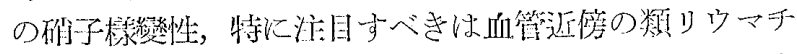
結䈱の出現等のアレルギー性組織變化を報じ，脚氣病像
の解析に對してアレルギーなる因子の附加の重要性を提 唱して居る，又中村的性，アレルギー㤬疾患患者の家系 調查に於いて非常に高窝に脚氣を登見し，所謂アレルギ 一素質者では脚氣万至脚氣棌师態に陷り易い事實を認 め，アレルギー素質を基礎として發比する疾蚛に脚氣を 加えて居るが，特に鈴汇により，衡心脚氣剖檢例の心㶓 にその75\%とい5䯩率に類リウマチ結節の出現を見た事

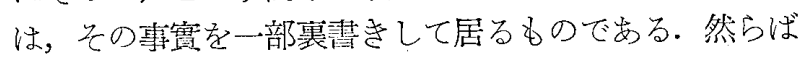
果して所霄りウマチ結節は纵體內に起るアレルギー性反 應の絬挔生じたと見做す(今迄の䍰績により)ならば，そ の主醴となるアレルゲンは何物であるかと言う事が問題 


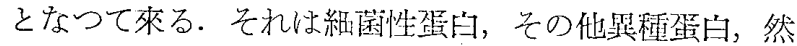
らざれば目家抗原性を持つに至つた自家蛋白でなければ

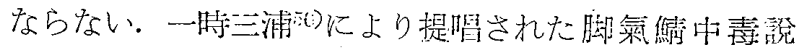
も，異程蛋白によるアレルギー證とも見做されない事も ない。乙かし脚氣の場合筋組織の退行性變化は著明なる のがあり，その崩壤産物によるアレルギーが極めて考兄

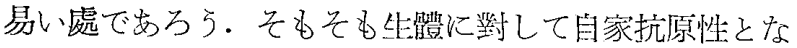

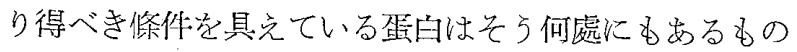

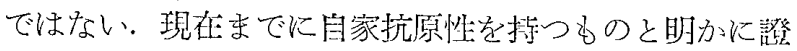

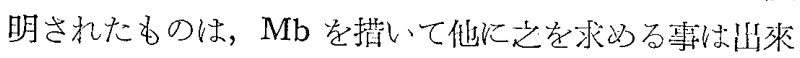
ないであろう。茲代於て私は，先ず日米病家第上り得た る $\mathrm{Mb}$ ，筋肉エキス，ミオジン麻びミオがンを以て家雭 を色疫して得たる抗血清を，輕い白米病の爿態保置いた

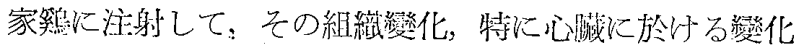
を檢傠して見た。然るに䁈歌成績に於て述べた加く，特

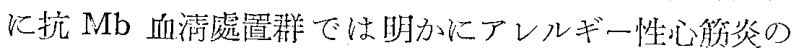

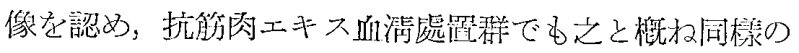
變化を觀察乙得た。次に白米病家第 $\mathrm{Mb}$ ，筋肉エ丰ス，

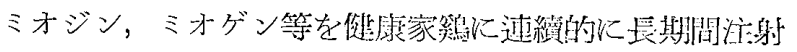

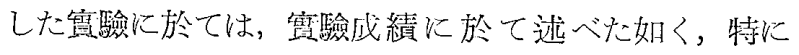
$\mathrm{Mb}$ 處置群化於て明かにアレルギー性心筋炎の像を認め

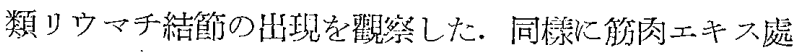

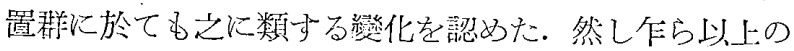
二つの大劋群を通じて，ミオジン，ミオゲンを以てする 場合の組織變化は及で筋肉エキスを以てする場命と比較

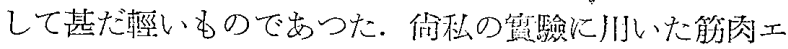
キスは元より多量の $\mathrm{Mb}$ が含有されて居り，この婜置 により起つた變化は主として筋闪土キス中の $\mathrm{Mb}$ の作 用による變化であると思われる。何故原らに゙筋肉エキス 中には, $\mathrm{Mb}$ の他にミオジン，ミオゲン等の筋掻白子存在

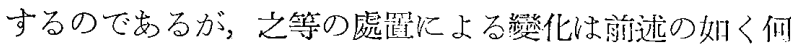

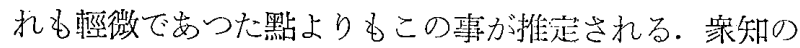
如く筋蛋白としてミオジン，ミオゲン，Mb 其の他樌及 學げられているが，この中で $\mathrm{Mb}$ は北大上野敋授門下 の業績で明かな如く，それが些腊內で或る種の變質を受 ける時，容易に自家抗原抗阯反應尒起し得るのは先ず且 家抗原性で特殊な地位を占めている Mb より外にない

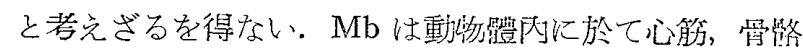

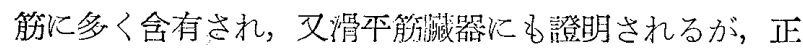
常な狀態に於ては之等の縕織哌器から遊離して存在する 事はないが，Günther(19)により多發性筋炎腎者尿中以

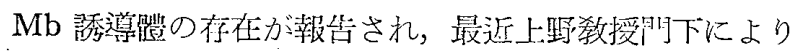
外傷坐ショック筫驗により尿中に $\mathrm{Mb}$ 物澌の遊活する

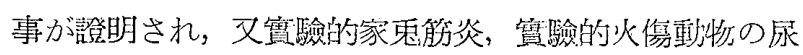
中に，或は蛊激な運動後に於ける動物，人䟧の尿中に夫

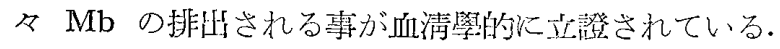

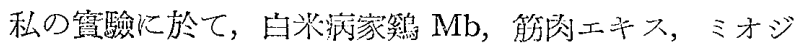

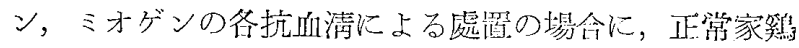

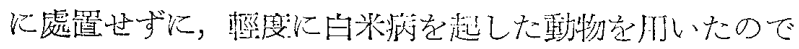
出る. 之は正常の狀態では助中に抗原か游活して存在し

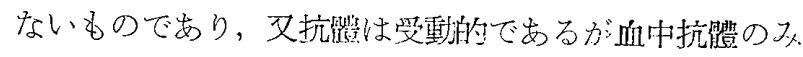

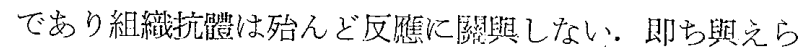

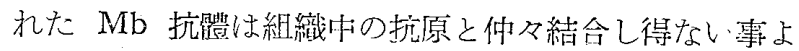
り考虑して，抗原遊活の機會のあるを考兄られる處の白

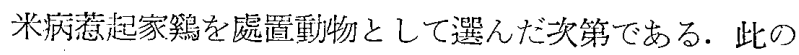
事は第 3 編第 2 章の賽騟成績から見ても首肯活來る處て

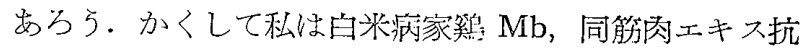
血垌の逨續注射に上り强いアレルギー性心筋炎を作り得

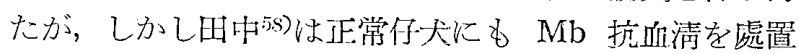

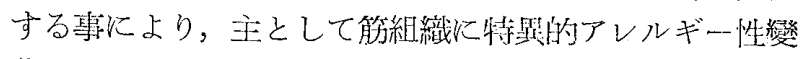
化，リウマチ結節の形成を認めて居る. 佮抗 $\mathrm{Mb}$ 血清

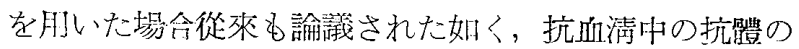

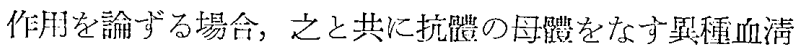

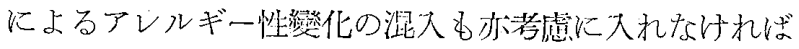

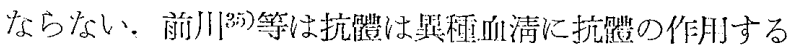

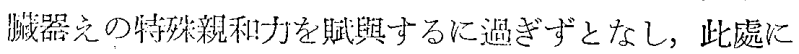

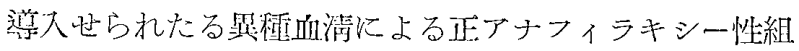

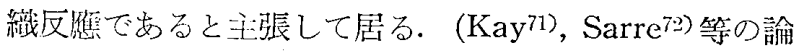
も概社之汇近い）しかし村上等は細胞毒素は先ず直接に

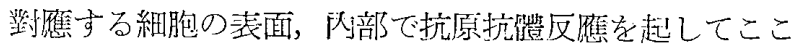

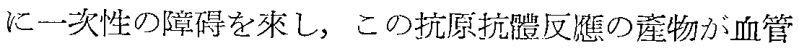

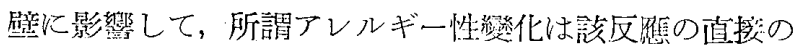
綃果ではなく隨件して起るものと述べて居る。私の蹖驗 では，抗血清と同樣方法で正常家鬼血清の注射を行つた が，其の場命心，骨路筋飞於て抗血清注射動物比比し其

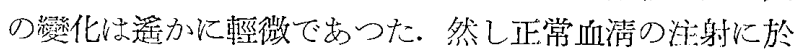

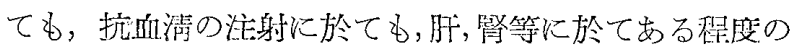
アレルギー㤬變化が存在しているのであるから, 全く異 檑血清としての作用を否定する事は出來ない. 然し簤際

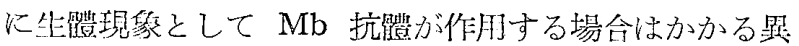
程血清の如き蛋白澧の媒介は殆えど考光られない，寧ろ

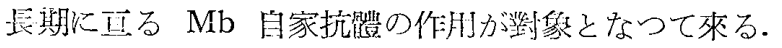

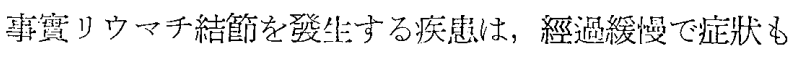

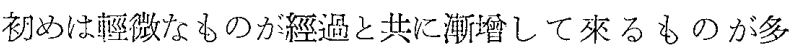

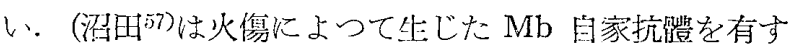

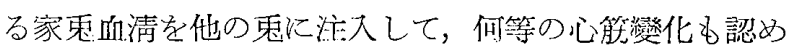
られなかつたと言つているが.)

茲に於て私は，白米病家第 $\mathrm{Mb}$ 及び筋肉エキスを健 康家籍に長期に亘り反䅇處置する事によつて如何なる組 織變化を告ずるかを檢䒺したのである，その結果は明か

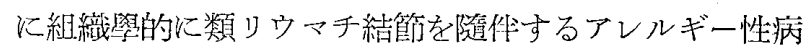

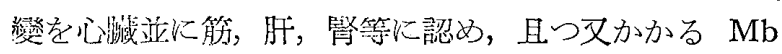

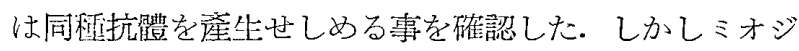
ン：ミオら゙ン等にはかかる性狀は㱠んぞ認められない。 缜のアレルギーの意味から言えば，A群は逆アナフィラ シー(Kay，前川に上ると正アナフィラシー)であつて睤 に浸々述べた樣に抗原は組織內の Mbであり,之は正常 の狀態では血中に遊铈して存在して居ないし，又抗嗹は

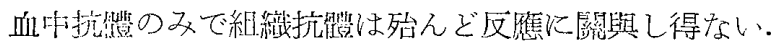

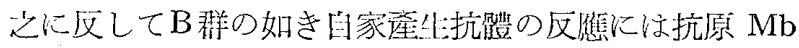


が皿中に存在し，又抗澧として血中抗腈の外にも組䋨抗 軆が同じく反篗の主役を古わている，從つてA群に比蔽

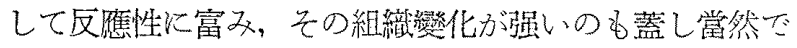

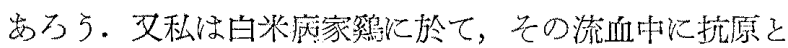

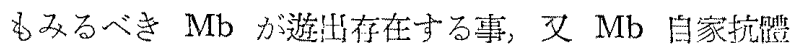
の裹生が見られる事を血清罣的に確認したし，更らに之

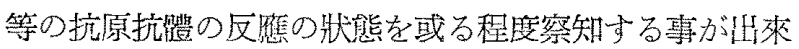
た. 此の事蜜は、沋の理論者更らに强く裹付けるるのて

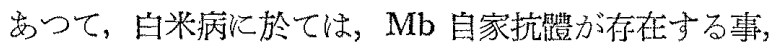

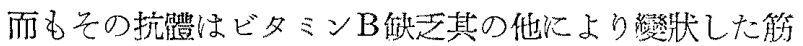
組織加ら游出した $\mathrm{Mb}$ に對萑して出來たもので，この 座生された， $\mathrm{Mb}$ 抗澧は多くはその遊出する $\mathrm{Mb}$ とて の筋局所に於て反隼し，その結果心欌，筋等に類りウ口 千結節学含さアレルギ一性變化を登生したものと考光ら れる.倘ビタミンB缺灭時組織蛋当が生化學的に加何に

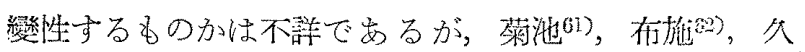

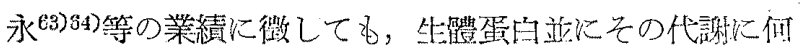

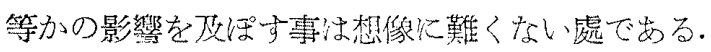

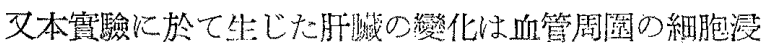

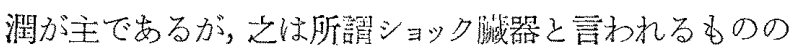

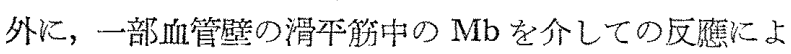
り，又肝境質の變化は一部 $\mathrm{Mb}$ 蛋白部分で女るグロビ

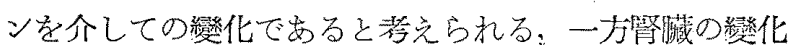

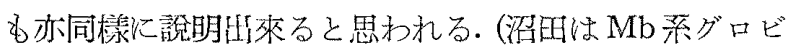

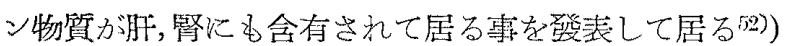

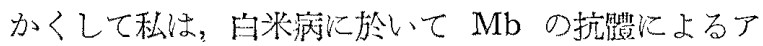
レルギー性反雔によつて類リウマチ結節を多隨作するア

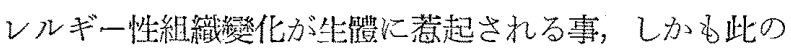
變化は實驗的に $\mathrm{Mb}$ 抗血清處置によるのみならず，同

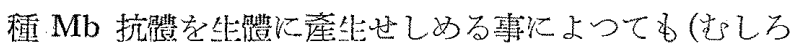

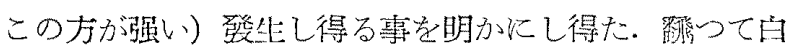
米病と脚氯との密接な攞係を認めるとするならば，上述

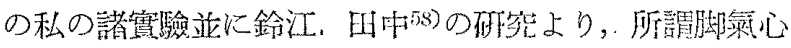

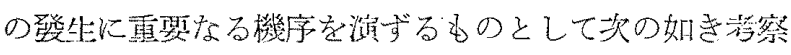
を下したいと思う。

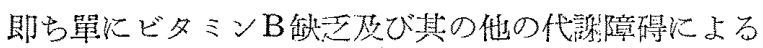
のみならず，更らに之等の障碍により箱組䋘の變筫（赫 壤）を來し，その同所より遊出也る戀性した $\mathrm{Mb}$ は，

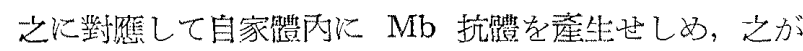
主として心筋中の Mb に反應してここに局所的抗原抗

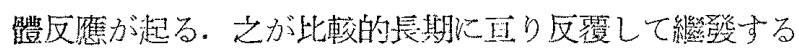

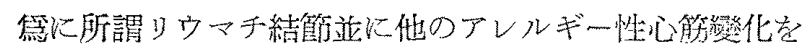

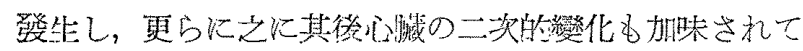

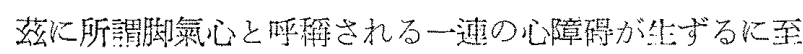
る良のと見られる。

（更らに私怔，かかる際の筋ホスファチードが如何なる 關係を持って居るか，此點を追求して居り，近く績嘏と

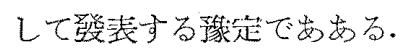

\section{第 5 編 結}

\section{論}

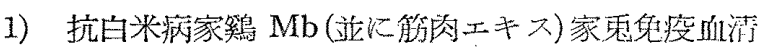

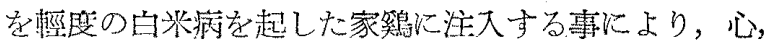

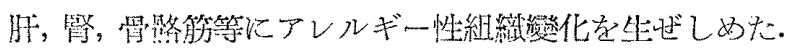

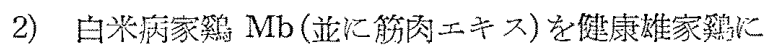

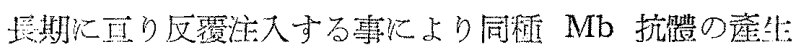

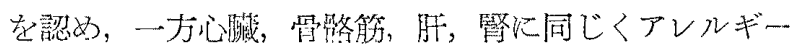

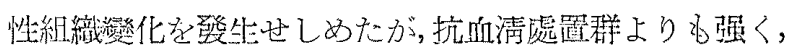
特に心践に類りウマチ結節の形成を諗めた。

3）然し他の筋蛋白であるミオジン，ミオゲン等には。 之等の特性性認められない。

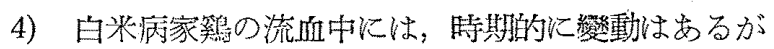

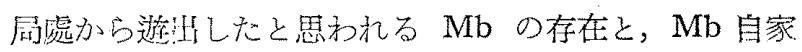

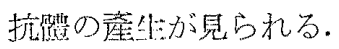

5）上上の成績に上り，白米病炕於けるリゥマチ結節

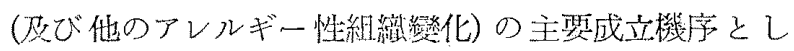

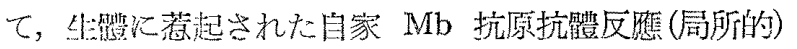

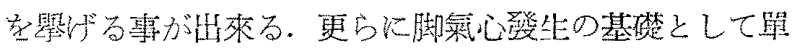

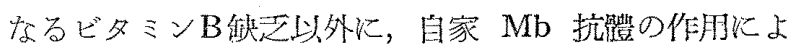
るテレルギー性因子の介在が安るるのと思う。

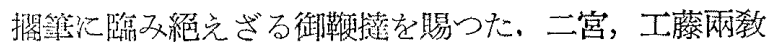
授，由村助效授，北大(現東大)上野教授，並に淔挼御指

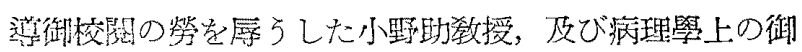

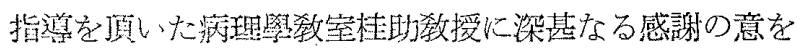
琵する。

(本諭文琴哥は第 16, 17 回日本循環器學會總會に於て

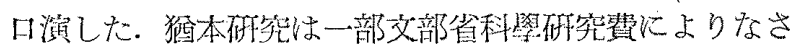
れた営光記与。)

\section{References}

1) Longcope, W. P.: J. of exper. med., 22, 793 (1915)

2) Boughton, T. H.: J. of imm., 2, 501 (1917)

3) Aschoff: Pathol. Anat., 1 Bd. (1936)

4) Klinge, F.: Dtsch. med. Wrsh 1529, (1936)

5) Klinge, F.: Beitr. z. path. Anat. z. allg. Pathol., 83,185 (1929)

6) Klinge, F.: Ergeb. d. allg. Pathol. u. pathol Anat. 27, (1933)

7) Vaubel, E.: Beitr. z. path. Anat. u. z. allg. Pathol., 89, 374 (1932)

8) Apitz, K.: Virchow's Arch., 289, 46 (1933)

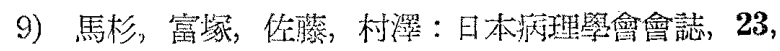
$533($ 眧 8)

10) Brunn, E.: Virchow's Arch., 393, 524 (1939)

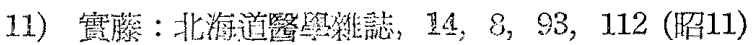

12) Auer, J.: J. of exper. med., 32, 427 (1920)

13) Knepper \& Wealer: Virchow's Arch., 294, 587 (1935)

14) Knepper, R. : Ebenda, 296, 364 (1936)

15) Kallos, P.: Fortschritte d. Allergie-lehre, 114 (1939)

16) Masugi, M.: Beitr. z. path. Anat, u. z. allg. 
Pathol., 91, 82 (1933)

17) Mingounov: Zit. n. W. Berger: Allergie, S. 117 (1940)

18) Rintelen, W.: Virchow's Arch.; 299, 629 (1937)

19) Klinge \& Rodrignez: Beitr. z. path. Anat. u. z. allg. Pathol., 103, 350 (1939)

20) Kaiserling, H.: Zit. n. W. Berger: Allergie, S. L19 (1940)

21) Kaiserling \& Ochse: Virchow's Arch., 299, 177 (1937)

22) Fischer \& Kaiserling: Ebenda, 297, 146 (1936)

23）武田，新保：北海道䂑誌，15，2967(昭12)

24) 野村：同誌，16，2819（昭13）

25) 兾滕：同誈，14，727 (昭11)

26) 大陑：日本循㻴器學誌，7，415，481 (炤17) 8, 23 85, 147, 187 (胎17)

27) Seegal, D. u. B.: Zit. n. W. Berger: Allergie, S. $239(1940)$

28) Riehm: Arch. Augenhk., 99, 438 (1928) 105, 82 (1931)

29）馬杉：干葉醫學會傕誌，6，1639（昭 3)

30）馬杉，堛域：同誌，9，1142（昭6)

31）馬杉，伀藤，藤堂：日本病理學會會誌，25，211 (昭10)

32) 滕堂 : 同誌，26，81 (畍11)

33) 藤堂：干葉醫學會雅誌，16,1121 (炤13)

34) Knepper, R. : Zit. n. W. Berger: Allergie, S. $116(1940)$

35）前川：醫界週報，342，5（昭16） 343，5 (昭16)

36）辻，近光，泉，菱田：日本內帉泌學會誌，14，1311 (昭13)

37）同人：日本病理學會新誌，30，460（昭15）

38) 宗：日本內分泌攀會誌， 16，682（昭15)

39) 近松 : 同誌，16，932，978 (昭15)

40) 野田：日本循瑞器學誌，11，153，156，160，163, $($ (I刀丁 22$)$

41）䕎田：同読，14，42，202（昭25） 14，239（昭26） 15, 28, 185 (昭26)

42) Lehmann-Facius, H: Klin. Wochenschr. 9, 24 $30(1930)$

43) 野田：日本循摆器學誌，12，1，4,9, 12 (炤23)

44）荒水，森澤：同誌，14，206(炤25) 14，240(炤26)

45）國分：同誌，12，220，223 (眧24) 13，223，254， 257 (炤24)
46）鉿木 : 同誌，13，50,53,231, 263 (昭24) 13，299， 301 (䧂25)

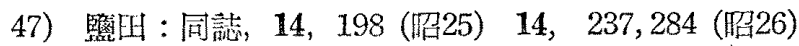
15, 181. (昭26)

48) M. Maekawa, M. D. : Acta Med. Univ. Kioto XXIIX, 175 (1951)

49) Günther: Virch. Arch. 230, 146 (1921) 251, 141 (1924)

Münch. Med. Wschr. 517 (1923)

50) Boerhaave: Instit. Med. 400 (1775)

51)小野：日新醫學， 35，4(昭23) 醫學之址物學，10，320（昭22）11，293（昭 22) 12,157 (䧂23)

52）上野：ミオグロビンの生理と病理. その血清學的

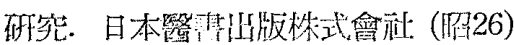

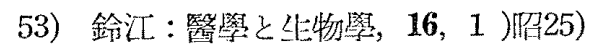

54）同人：日本㗨事新報，No. 1322，1701（哪24）

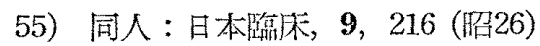
最新整學，5，718（炤25）

56）三浦：三浦守治諭文全策 (大7)

57）沼田：法埃學誌，3，6(䧂24)

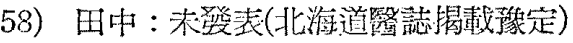

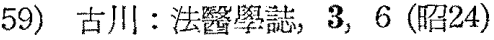

60）尾崎：未發表

61）菊池：大警會誌，40，174（炤15)

62) 布揓：日纯化報，12，267 (昭12)

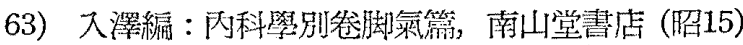

64） 久永：日本內科學誌(總會號) 40，216（炤26）

65) 中村 : 最新短學，2，437(昭22)

66)网林：兔度とアレッギー，1（昭26）

67）緒方他三民：日新醫學，13,3,4,5（大13)

68) S. Takeda: Acta med. Univ. Kioto XXVII, 3, 231 (1950)

69) S. Torii : Acta med. Univ. Kioto XXIIX, 1, 28, (1950)

70) O. v. Fürth : Arch. f. exp. Pharm. u. Path. 36, 231 (1895)

71) Kay. C: J. Exp. Med. 72, 669 (1940) Amer.J. Med. Sei. 204, 483 (1942)

72) H. Sarre: Dtsch. Med. Wsch. 77 (38), 1158 (19 52)

73) 荻野：日本循環器學誌， 16，7，8（昭27）

74）鈴江：リウマチ新旒，第 1 版 